In addition to the well-illustrated account of the methods of wood-testing adopted by the U.S. Forest Service, a useful bibliography of the subject, and particularly a list of less-known American papers, gives value to the book. P. G.

\section{WATER REPTILES.}

Water Reptiles of the Past and Present. By Prof. S. W. Williston. Pp. vii $+25 \mathrm{I}$. (Chicago: University of Chicago Press; London: Cambridge University Press, n.d.) Price I $2 s$. net.

TUST as it is clear that the existing whales and porpoises are descended from quadrupeds which formerly lived on land, it is gradually being recognised that the marine reptiles which occupied their place during the Secondary Period of geological time also had land-ancestors. Many of the connecting links can now be traced among the fossils discovered during recent years, and so much progress has been made in interpreting them that it is interesting to pause and survey the result. The original papers are scattered through special journals, some of them not easily accessible, and it is necessary to collect the essential facts from numerous sources. We therefore welcome the small book by Prof. Samuel W. Williston, who has devoted many years to the successful study of these reptiles and now reviews the subject exhaustively with first-hand knowledge.

Though the work is mainly suited for students who have some preliminary acquaintance with vertebrate palæontology, Prof. Williston hopes to attract more general readers by a series of introductory chapters dealing with a few elementary geological considerations, and with the structure of the reptilian skeleton and its various modifications in those animals which are adapted for life in water. He then treats the groups of water reptiles in systematic order, referring to the few that survive as well as the great tribes of extinct forms. The descriptions are illustrated both by drawings of the skeletal remains themselves and by many spirited restorations, some original and others by well-known authorities. The technical accounts of structure, indeed, are followed in all cases by a discussion of the inferences they suggest as to the habits and mode of life of the animals in question. All the chapters are well up-to-date, and that on the Cretaceous Mosasauria is especially interesting from its intimate connection with the author's own researches.

As we turn over the pages of this book we are led to speculate as to why nearly all these groups NO. 2366, VOL. 95] of water reptiles, so widely distributed in every sea, suddenly became extinct at the end of the Secondary Period, without coming in contact with the whales and porpoises which in later times took their pilace. Prof. Williston can only suggest that the races may have become effete and died of old age. It is evident that the mystery still awaits solution.

A. S. W.

\section{MIND AND MATTER.}

(I) The Master-Key: a New Philosophy. By D. Blair. Pp. I 8 . (Wimbledon: Ashrama Agency, I914.) Price 3s. 6d. net.

(2) Essays on the Life and Work of Newton. By A. de Morgan, edited by P. E. B. Jourdain. Pp. xiii + 198. (Chicago and London: The Open Court Publishing Co., I9I4.) Price 5s. net.

(3) The Analysis of Sensations and the Relation of the Physical to the Psychical. By Dr. E. Mach. Translated by C. M. Williams. Pp. $\mathrm{xv}+380$. (Chicago and London: The Open Court Publishing Co., I9I4.) Price $6 s .6 d$. net.

(4) Proceedings of the Aristotelian Society. New series, vol. xiv. Pp. 438. (London: Williams and Norgate, I9I4.) Price Ios. $6 d$. net.

(5) The Philosophy of Change: a Study of the Fundamental Principle of the Philosophy of Bergson. By Dr. H. W. Carr. Pp. xii +216. (London: Macmillan and Co., Ltd., I9I4.) Price 6s, net.

(r) THE writer condemns himself by his own "new philosophy," and is writing another book"The Truth about the Other World"-which "will be the first genuine Revelation ever published." In the volume under notice he discusses all things in heaven and earth, from the solar spectrum, heredity, and space, to Platonism, hallucinations, and Vedanta. There is evidence of a great deal of heterogeneous and elementary knowledge, but all is confused and superficial. Apparently the author finds salvation in the word Monad--though he does not expound Leibnizbut his explanations do not explain much. $\mathrm{He}$ posits a "nerve-ether" which is quite different from the luminiferous æther, which latter is "no use" to him; and he seems to have a very poor opinion of the Royal Society. No doubt the society will survive.

(2) These reprinted essays, written more than half-a-century ago, are still worth reading, both for their matter and their style. De Morgan was an able mathematician, he made careful researches into the details of Newton's life and controversies. and he had a very characteristic wit. His treatment of Newton is respectful yet critical. Sir 